\title{
Pengaruh Human Capital Terhadap Durasi Menganggur Pada Pekerja Yang Terkena PHK Akibat Pandemi Covid-19
}

\author{
(The Effect of Human Capital on the Duration of Unemployment For Workers Affected by Layoffs \\ Due to the Covid-19 Pandemic)
}

Fitriani Aditya Putri

Universitas Indonesia

E-mail: fitriani.aditya@ui.ac.id

\begin{abstract}
ABSTRAK
Tingkat Pengangguran Terbuka mengalami peningkatan di era pandemi Covid-19. Studi ini bertujuan untuk menganalisis sejauh mana pengaruh human capital (pendidikan dan pelatihan) terhadap durasi menganggur pada pekerja yang terkena PHK akibat pandemi Covid-19 di Indonesia. Studi ini diharapkan dapat memberikan gambaran terkait pentingnya human capital dalam mengurangi pengangguran di Indonesia akibat pandemi Covid-19. Hasil estimasi menggunakan regresi Cox menunjukkan bahwa semakin tinggi tingkat pendidikan pekerja yang terkena PHK akibat pandemi Covid-19 maka semakin lambat keluar dari pengangguran. Sedangkan, pekerja yang pernah terkena PHK akibat pandemi Covid-19 yang pernah mengikuti pelatihan bersertifikat memiliki risiko keluar dari pengangguran yang lebih cepat dibandingkan tidak pernah mengikuti pelatihan bersertifikat. Berdasarkan hasil penelitian dapat disimpulkan bahwa investasi human capital berupa pelatihan dapat mempercepat durasi menganggur pada pekerja yang terkena PHK akibat pandemi Covid-19 di Indonesia, sedangkan semakin tinggi investasi pada pendidikan justru memperlambat durasi menganggur.
\end{abstract}

Kata kunci: human capital, pengangguran, durasi menganggur

\begin{abstract}
Unemployment Rate has increased in the era of the Covid-19 pandemic. This study aims to analyze the influence of human capital (education and training) on the duration of unemployment in workers who have been laid off due to the Covid-19 pandemic in Indonesia. This study is expected to provide an overview of the importance of human capital in reducing unemployment in Indonesia due to the Covid-19 pandemic. The estimation results using Cox regression show that the higher of education level of workers who have been laid off due to the Covid-19 pandemic, the slower they will come out of unemployment. Meanwhile, workers who have been laid off due to the Covid-19 pandemic who have attended certified training have the risk of leaving unemployment faster than those who have never attended certified training. Based on the results of the study, it can be concluded that human capital investment in the form of training can accelerate the duration of unemployment for workers who have been laid off due to the Covid-19 pandemic in Indonesia, while the higher investment in education actually slows the duration of unemployment.
\end{abstract}

Keywords: human capital, unemployment, duration of unemployment

\section{PENDAHULUAN}

\section{Latar Belakang}

Pandemi Covid-19 memberikan dampak yang cukup signifikan dalam berbagai sektor di dunia, salah satunya sektor ekonomi (ILO, 2020). ILO (2020) juga menjelaskan bahwa banyak negara membatasi kegiatan ekonomi akibat kebijakan menjaga jarak sosial (social distancing), sehingga mempengaruhi sektor ekonomi yang berimplikasi pada penurunan lapangan kerja. Oleh karena itu, pandemi Covid-19 mengakibatkan permintaan tenaga kerja terguncang di pasar tenaga kerja, sehingga banyak pekerja yang kehilangan pekerjaan baik sementara maupun permanen (OECD, 2020).

Di Indonesia, pandemi Covid-19 menyebabkan beberapa perusahaan bahkan cenderung terpaksa melakukan Pemutusan Hubungan Kerja (PHK) kepada pekerjanya, yang kemudian meningkatkan Tingkat Pengangguran Terbuka (TPT). Berdasarkan data Survei Angkatan Kerja Nasional (Sakernas) Agustus, TPT di Indonesia meningkat dari 5,28 persen di tahun 2019 menjadi 7,07 persen di tahun 2020. Padahal berdasarkan hasil Sakernas Agustus, tingkat pengangguran terbuka (TPT) di Indonesia sejak tahun 2006 hingga tahun 2019 cenderung secara terus menerus menurun, dengan rata-rata penurunan sebesar 0,43 persen per tahun. 
Tingginya tingkat pengangguran terbuka di era pandemi Covid-19 menarik untuk diteliti lebih lanjut, terutama pengangguran yang mengalami PHK akibat pandemi Covid-19. Di era pandemi Covid-19, mendapatkan pekerjaan pasca mengalami PHK tidaklah mudah, tenaga kerja yang tidak memiliki pengalaman dan keahlian maka peluangnya kecil untuk diterima kembali bekerja (OECD, 2020), sehingga dapat memperpanjang durasi menganggur.

Berbagai studi telah dilakukan bahwa durasi menganggur dipengaruhi oleh tingkat pendidikan (Grogan \& Van Den Berg, 2001; Tansel \& Tasci, 2004) dan partisipasi pelatihan (Crépon et al., 2012). Namun, belum banyak yang meneliti terkait peran human capital (pendidikan dan pelatihan) terhadap durasi menganggur di era pandemi Covid-19, terutama pada pekerja yang mengalami PHK akibat pandemi Covid-19. Pendidikan dan pelatihan merupakan investasi yang penting dalam modal manusia (human capital) dan memiliki pengaruh terhadap pekerjaan (Becker, 1962). Oleh karena itu, studi ini bertujuan untuk menganalisis sejauh mana pengaruh human capital terhadap durasi menganggur pada pekerja yang terkena PHK akibat pandemi Covid-19 di Indonesia.

Studi ini diharapkan dapat memberikan gambaran terkait pentingnya human capital dalam mengurangi pengangguran di Indonesia akibat pandemi Covid-19. Hipotesis yang akan diuji dalam studi ini adalah: Investasi human capital (pendidikan dan pelatihan) mempercepat durasi menganggur pada pekerja yang terkena PHK akibat pandemi Covid-19 di Indonesia.

\section{Tinjauan Pustaka}

Pada bagian ini akan dibahas landasan penelitian terkait pengangguran dan durasi menganggur yang dihubungkan dengan human capital (pendidikan dan pelatihan) pada tenaga kerja. Menurut Borjas (2015) bahwa pengangguran terjadi karena adanya ketidakseimbangan antara permintaan dan penawaran tenaga kerja. Selain itu juga dijelaskan bahwa seseorang yang menganggur dikarenakan berbagai alasan seperti sengaja berhenti, diberhentikan, baru mulai memasuki pasar kerja, dan masuk kembali ke pasar kerja. Borjas (2015) juga menjelaskan tentang keputusan individu untuk bekerja atau menganggur yang dikaitkan dengan teori upah reservasi (reservation wage) dalam menganalisa perilaku penawaran tenaga kerja. Individu memutuskan menganggur jika upah pasar kurang dari upah reservasi. Namun, jika upah pasar melebihi upah reservasi maka individu tersebut memutuskan untuk memasuki pasar tenaga kerja.

Durasi menganggur (lama mencari kerja) berkaitan dengan job search theory. Mccall et al., (1970) mengembangkan job search model yang menganalisa perilaku pengangguran berkaitan dengan durasi menganggur. Menurut Mccall et al., (1970), durasi menganggur tergantung dari tingkat upah yang diinginkan seseorang sesuai keahlian yang dimilikinya dan opportunity cost selama mencari pekerjaan. Jika seseorang merasa keahliannya sangat tinggi, maka tawaran pekerjaan yang lebih rendah dari harapannya akan ditolak dan memilih untuk tetap menganggur. Borjas (2015) juga manyatakan bahwa seseorang bersedia untuk lebih lama menganggur karena dapat mengarah pada pekerjaan dengan upah yang lebih tinggi. Pengangguran yang mencari kerja merupakan suatu bentuk investasi modal manusia, yaitu investasi dalam informasi terkait pasar tenaga kerja. Pengangguran yang semakin lama mencari kerja maka semakin panjang durasi menganggurnya.

Disamping itu, Becker (1962) dengan teori human capital menyatakan bahwa investasi yang penting dalam modal manusia (human capital) adalah pendidikan dan pelatihan yang memiliki pengaruh terhadap pekerjaan. Borjas (2015) juga menyatakan bahwa pendidikan menurunkan tingkat pengangguran. Pekerja terdidik lebih banyak mengikuti pelatihan kerja karena pelatihan khusus akan "mengawinkan" perusahaan dengan pekerja. Perusahaan cenderung memberhentikan pekerja yang berpendidikan ketika dihadapkan pada kondisi ekonomi yang merugikan perusahaan. Ketika pekerja terdidik beralih pekerjaan maka tidak mengalami periode pengangguran yang panjang. Selain itu, pekerja yang berpendidikan mendapat banyak informasi atau memiliki jaringan yang lebih baik terkait pekerjaan alternatif.

Studi terkait durasi menganggur telah dilakukan oleh Grogan \& Van Den Berg (2001) di Rusia yang menggunakan data Russian Longitudinal Monitoring Survey (RLMS) 1994-1996 dengan metode estimasi Proportional Hazard Model. Hasil penelitiannya menunjukkan bahwa perempuan mempunyai durasi menganggur yang lebih pendek dibandingkan laki-laki. Kemudian, tenaga kerja yang berpendidikan tinggi memiliki durasi menganggur yang lebih pendek dibandingkan berpendidikan rendah. Selain itu, tenaga kerja yang semakin tua maka semakin panjang durasi menganggurnya.

Selain itu, studi Tansel \& Tasci (2004) menganalisis determinan durasi menganggur di Turki yang menggunakan data Household Labor Force Survey (HLFS) 2000-2001 dengan metode estimasi PSM, Log Normal, dan Log Logistic. Hasil studi tersebut menunjukkan bahwa tingkat pendidikan yang semakin tinggi maka peluang keluar dari pengangguran semakin meningkat. Peluang perempuan keluar dari pengangguran 
lebih rendah dibandingkan laki-laki. Laki-laki yang berstatus kawin memiliki peluang keluar dari pengangguran yang lebih besar dibandingkan perempuan yang berstatus kawin. Selain itu, semakin bertambahnya umur maka peluang keluar dari pengangguran semakin rendah dan tinggal di perkotaan memiliki peluang keluar dari pengangguran lebih besar dibandingkan di perdesaan.

Sedangkan studi dari Pasay \& Indrayanti (2012) yang menggunakan data Sakernas 2010 dengan metode estimasi Ordinary Least Square (OLS) menunjukkan hasil bahwa tingkat pendidikan yang semakin tinggi maka cenderung semakin lama durasi menganggur (lama mencari kerja). Hal ini dikarenakan tenaga kerja yang berpendidikan menengah ke bawah, tidak banyak menuntut persyaratan dalam menerima pekerjaan, sehingga mereka dapat dengan mudah terserap di pasar kerja. Selain itu, hasil penelitian juga menunjukkan bahwa individu yang berstatus kawin cenderung lebih lama durasi menganggurnya dibandingkan individu yang berstatus selain kawin. Sedangkan semakin muda seseorang cenderung semakin lama durasi menganggur.

\section{METODE}

\section{Sumber Data}

Studi ini menggunakan data cross section dari hasil Survei Angkatan Kerja Nasional (Sakernas) Agustus tahun 2020 yang bersumber dari Badan Pusat Statistik (BPS). Pada penelitian ini menggunakan data Sakernas Agustus 2020 karena survei ini mengumpulkan informasi tentang dampak pandemi Covid-19 terhadap ketenagakerjaan di Indonesia.

\section{Sampel dan Responden}

Unit analisis dalam penelitian ini dibatasi pada angkatan kerja di Indonesia yang memiliki pengalaman pernah mengalami Pemutusan Hubungan Kerja (PHK) akibat pandemi Covid-19. Jumlah responden pada angkatan kerja yang mengalami PHK karena pandemi Covid-19 sebanyak 3.716 sampel responden.

\section{Kerangka Analisis}

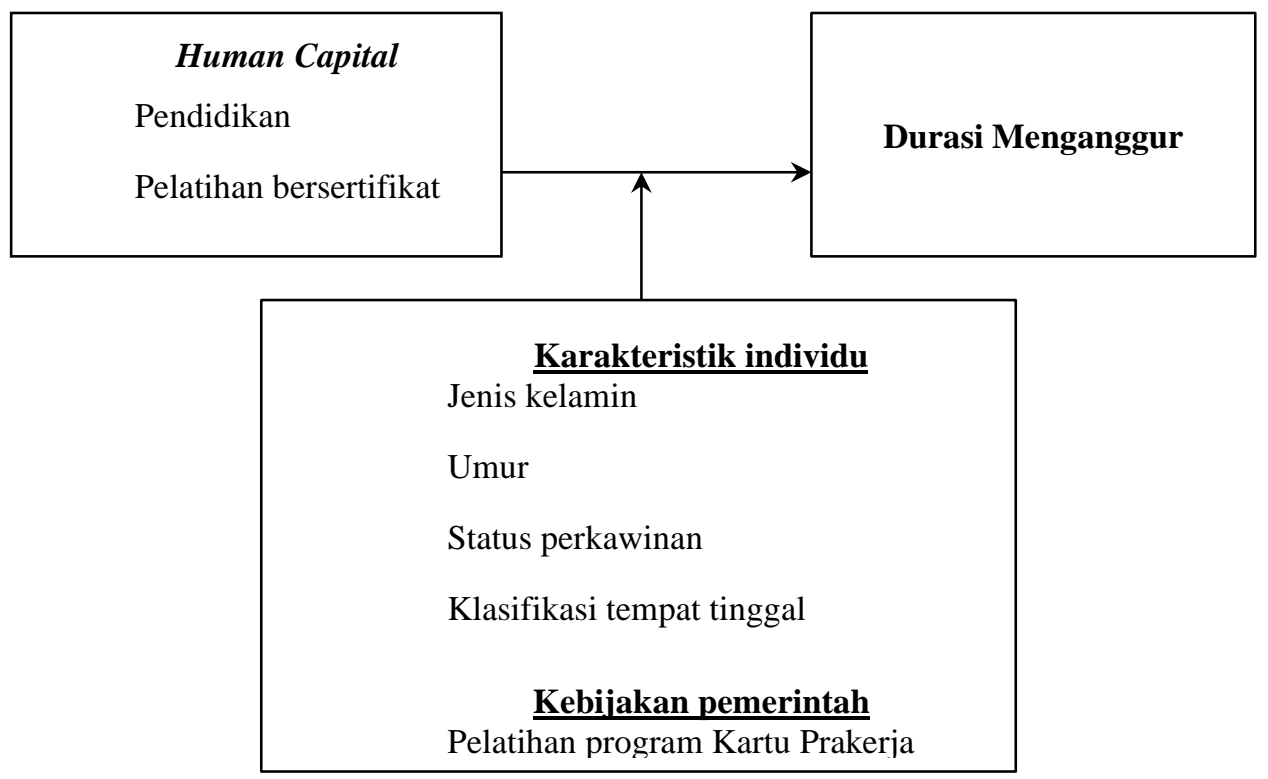

Gambar 1. Kerangka Analisis

Pada penelitian ini menggunakan analisis deskriptif dan analisis inferensial. Analisis deskriptif digunakan untuk membahas gambaran umum angkatan kerja yang mengalami PHK akibat pandemi Covid19. Sedangkan analisis inferensial digunakan untuk membahas hubungan antara human capital (pendidikan dan pelatihan) dengan durasi menganggur pada angkatan kerja yang mengalami PHK akibat pandemi Covid19. Selain itu, penelitian ini juga dikontrol dengan karakteristik individu (jenis kelamin, umur, status perkawinan, dan klasifikasi tempat tinggal) dan kebijakan pemerintah (pelatihan program Kartu Prakerja). 


\section{Definisi Operasional}

Definisi operasional variabel dalam penelitian ini mengacu pada konsep dan definisi yang digunakan oleh Badan Pusat Statistik (BPS, 2020) dalam pengumpulan data ketenagakerjaan.

Tabel 1. Definisi Operasional Variabel.

\begin{tabular}{|c|c|c|}
\hline Nama Variabel & Definisi Variabel & Kategori \\
\hline \multicolumn{3}{|c|}{ Variabel Terikat } \\
\hline Waktu survival $(t)$ & $\begin{array}{l}\text { Lamanya waktu yang diperlukan untuk mencari } \\
\text { pekerjaan/mempersiapkan usaha (bulan) }\end{array}$ & $\begin{array}{l}\text { Durasi menganggur } \\
\text { (dalam bulan) }\end{array}$ \\
\hline Sensor & $\begin{array}{l}\text { Durasi tidak tersensor : durasi kejadian yang } \\
\text { lengkap (mengalami event) }\end{array}$ & $\begin{array}{l}0=\text { Individu masih } \\
\text { menganggur* }\end{array}$ \\
\hline & $\begin{array}{c}\text { Data tersensor : durasi kejadian yang tidak } \\
\text { lengkap (tidak mengalami event) }\end{array}$ & $1=$ Individu telah bekerja \\
\hline \multicolumn{3}{|c|}{ Variabel Bebas Utama } \\
\hline $\begin{array}{l}\text { Pendidikan tertinggi yang } \\
\text { ditamatkan (Didik) }\end{array}$ & $\begin{array}{l}\text { Tingkat pendidikan yang paling tinggi ditamatkan } \\
\text { oleh penduduk usia } 15 \text { tahun dan lebih pada }\end{array}$ & $\begin{array}{c}0=\text { Tidak sekolah/tidak tamat } \\
\text { SD }^{*}\end{array}$ \\
\hline & jenjang pendidikan formal & $\begin{array}{c}1 \text { = Tamat SD atau SMP } \\
2 \text { = Tamat SMA/ SMK } \\
3 \text { = Tamat Perguruan Tinggi }\end{array}$ \\
\hline $\begin{array}{l}\text { Pelatihan bersertifikat } \\
\text { (Training) }\end{array}$ & $\begin{array}{c}\text { Kegiatan peningkatan keterampilan tertentu yang } \\
\text { bersifat khusus pada batas waktu tertentu dan } \\
\text { memperoleh sertifikat } \\
\text { Variabel Bebas Kontrol }\end{array}$ & $\begin{array}{c}0=\text { Tidak pernah berpartisipasi } \\
1=\text { Pernah berpartisipasi }\end{array}$ \\
\hline Pelatihan program Kartu & Mendaftar dan lolos seleksi program kartu & $0=$ Tidak berpartisipasi $^{*}$ \\
\hline Prakerja (Prakerja) & $\begin{array}{l}\text { prakerja serta menyelesaikan pelatihan pada } \\
\text { program kartu prakerja }\end{array}$ & $1=$ Berpartisipasi \\
\hline Umur (Umur) & Umur pada ulang tahun terakhir & 15 tahun dan lebih \\
\hline Jenis kelamin (Laki) & Jenis kelamin berdasarkan jawaban responden & $\begin{array}{c}0=\text { Perempuan* } \\
1 \text { = Laki-laki }\end{array}$ \\
\hline Status perkawinan (Kawin) & Status perkawinan & $\begin{array}{c}0=\text { Lainnya }^{*} \\
1=\text { Kawin }\end{array}$ \\
\hline $\begin{array}{l}\text { Klasifikasi tempat tinggal } \\
\text { (Urban) }\end{array}$ & Klasifikasi tempat tinggal & $\begin{array}{c}0=\text { Desa }^{*} \\
1=\text { Kota }\end{array}$ \\
\hline
\end{tabular}

\section{Metode Analisis}

Metode yang digunakan dalam penelitian ini adalah metode analisis deskriptif dan analisis inferensial. Metode analisis inferensial yang digunakan dalam studi ini adalah analisis regresi Cox. Dalam menganalisis data set waktu (durasi menganggur), lebih tepat menggunakan analisis survival dalam hal ini menggunakan Proportional Hazard Model atau Regresi Cox, karena data set waktu (durasi menganggur) cenderung tidak berdistribusi normal. Pada penelitian ini variabel bebas utamanya adalah tingkat pendidikan dan partisipasi pelatihan. Sedangkan variabel terikat adalah durasi menganggur (waktu survival).

\section{Model Penelitian}

Model persamaan umum yang digunakan pada studi ini sebagai berikut:

$$
\begin{aligned}
\operatorname{Ln} \frac{h_{1}(t)}{h_{0}(t)}= & \beta_{0}+\beta_{1} \text { Didik } 1+\beta_{2} \text { Didik } 2+\beta_{3} \text { Didik } 3+\beta_{4} \text { Training }+\beta_{5} \text { Prakerja }+ \\
& +\beta_{6} \text { Umur }+\beta_{7} \text { Laki }+\beta_{8} \text { Kawin }+\beta_{9} \text { Urban }
\end{aligned}
$$

dengan: $h_{1}(t)$ adalah fungsi hazard (risiko keluar dari pengangguran);

$h_{0}(t)$ adalah baseline fungsi hazard (risiko keluar dari pengangguran)

\section{HASIL DAN PEMBAHASAN}

\section{Gambaran Umum Sampel Penelitian}

Berdasarkan data Sakernas Agustus 2020 tanpa pembobotan, penduduk usia kerja yang mengalami PHK akibat pandemi Covid-19 sebesar 3.944 atau sekitar 0,50 persen dari sampel penduduk usia kerja. 
Jumlah angkatan kerja yang mengalami PHK akibat pandemi Covid-19 sebanyak 3.716 unit analisis, dengan status bekerja sebanyak 48,8 persen dan pengangguran sebanyak 51,2 persen (Tabel 2).

Tabel 2. Kondisi Ketenagakerjaan yang Terkena PHK Akibat Pandemi Covid-19.

\begin{tabular}{lrr}
\hline Penduduk Usia Kerja & $\mathrm{N}$ & $\%$ \\
\hline Angkatan Kerja & 3.716 & 94,2 \\
Bekerja & 1.813 & 48,8 \\
Pengangguran & 1.903 & 51,2 \\
Bukan Angkatan Kerja & 228 & 5,8 \\
Total & 3.944 & 100,0 \\
\hline
\end{tabular}

Sumber: Sakernas Agustus 2020, BPS (diolah)

Berdasarkan tabel 3 ditunjukkan bahwa rata-rata durasi menganggur pada angkatan kerja yang telah kembali bekerja setelah mengalami PHK akibat dampak pandemi Covid-19 adalah 1,57 bulan. Sedangkan, rata-rata durasi menganggur pada angkatan kerja yang masih menganggur setelah mengalami PHK akibat dampak pandemi Covid-19 adalah 3,93 bulan. Selain itu, berdasarkan tabel 3, rata-rata angkatan kerja yang mengalami PHK akibat dampak pandemi Covid-19 berumur 31,51 tahun.

Tabel 3. Distribusi Angkatan Kerja yang Terkena PHK Akibat Pandemi Covid-19 (Variabel Numerik).

\begin{tabular}{lcc}
\hline \multicolumn{1}{c}{ Variabel } & $\mathrm{N}$ & Rata-rata \\
\hline $\begin{array}{l}\text { Durasi menganggur } \\
\text { (Data tidak tersensor: Individu telah bekerja) }\end{array}$ & 1.813 & 1,57 \\
$\begin{array}{l}\text { Durasi menganggur } \\
\text { (Data tersensor: Individu masih menganggur) }\end{array}$ & 1.903 & 3,93 \\
Umur & 3.716 & 31,51 \\
\hline
\end{tabular}

Sumber: Sakernas Agustus 2020, BPS (diolah)

Tabel 4. Distribusi Angkatan Kerja yang Terkena PHK Akibat Pandemi Covid-19 (Variabel Kategorik).

\begin{tabular}{llrr}
\hline & Variabel & N & \% \\
\hline Pendidikan & Tidak Sekolah/Tidak Tamat SD & 103 & 2,77 \\
& Tamat SD atau SMP & 949 & 25,54 \\
& Tamat SMA/SMK & 2.259 & 60,79 \\
& Tamat Perguruan Tinggi & 405 & 10,90 \\
& Total & $\mathbf{3 . 7 1 6}$ & $\mathbf{1 0 0 , 0 0}$ \\
Partisipasi Pelatihan & Pernah & 725 & 19,51 \\
Bersertifikat & Tidak Pernah & 2.991 & 80,49 \\
& Total & $\mathbf{3 . 7 1 6}$ & $\mathbf{1 0 0 , 0 0}$ \\
Partisipasi Pelatihan & Pernah & 46 & 1,24 \\
Program Kartu Prakerja & Tidak Pernah & 3.670 & 98,76 \\
& Total & $\mathbf{3 . 7 1 6}$ & $\mathbf{1 0 0 , 0 0}$ \\
Jenis Kelamin & Laki-laki & 2.579 & 69,40 \\
& Perempuan & 1.137 & 30,60 \\
Klasifikasi Tempat Tinggal & Total & $\mathbf{3 . 7 1 6}$ & $\mathbf{1 0 0 , 0 0}$ \\
& Kota & 2.595 & 69,83 \\
& Desa & 1.121 & 30,17 \\
Status Perkawinan & Total & $\mathbf{3 . 7 1 6}$ & $\mathbf{1 0 0 , 0 0}$ \\
& Kawin & 1.759 & 47,34 \\
& Lainnya & 1.957 & 52,66 \\
& Total & $\mathbf{3 . 7 1 6}$ & $\mathbf{1 0 0 , 0 0}$ \\
\hline
\end{tabular}

Sumber: Sakernas Agustus 2020, BPS (diolah)

Pada tabel 4, menurut tingkat pendidikan, mayoritas angkatan kerja yang mengalami PHK akibat pandemi Covid-19 adalah yang berpendidikan tamat SMA/SMK sebesar 60,79 persen. Hal ini dikarenakan pada sektor formal cenderung merekrut pekerja yang memiliki pendidikan tinggi, sehingga banyak pekerja yang mengalami PHK adalah pekerja yang berpendidikan tamat SMA/SMK dibandingkan pekerja yang 
tamat perguruan tinggi. Sektor formal cenderung mempertahankan pekerja yang tamat perguruan tinggi untuk kelangsungan perusahaan, karena dinilai lebih kompeten dan lebih menguntungkan bagi perusahaan saat pandemi Covid-19.

Setelah itu, angkatan kerja yang mengalami PHK akibat pandemi Covid-19 adalah yang berpendidikan tamat SD atau SMP sebesar 25,54 persen, tamat perguruan tinggi sebesar 10,90 persen, dan tidak sekolah/tidak tamat SD sebesar 2,77 persen. Pekerja yang tidak sekolah/tidak tamat SD paling sedikit mengalami PHK karena pekerjaan di sektor formal dengan kualifikasi pendidikan rendah tersebut sangat sedikit dan cenderung sebagai pekerja kontrak, misal: cleaning service, office boy, satpam, dan lain-lain.

Jika dilihat dari partisipasi pelatihan, angkatan kerja yang mengalami PHK akibat pandemi Covid-19 yang pernah mengikuti pelatihan bersertifikat dan pelatihan program Kartu Prakerja sebesar 19,51 persen dan 1,24 persen. Rendahnya keterampilan pekerja disinyalir menjadi salah satu faktor yang menyebabkan pekerja rentan mengalami PHK di era pandemi Covid-19.

Selain itu, perbandingan laki-laki dan perempuan pada angkatan kerja yang mengalami PHK akibat pandemi Covid-19 adalah 69,40 persen dan 30,60 persen. Apabila dilihat dari klasifikasi tempat tinggal, angkatan kerja yang berada di perkotaan lebih dominan yang mengalami PHK dibandingkan dengan angkatan kerja yang berada di perdesaan dengan perbandingan 69,83 persen dan 30,17 persen. Jika dilihat dari status perkawinan, angkatan kerja yang berstatus tidak kawin lebih banyak mengalami PHK akibat pandemi Covid-19 sebesar 52,66 persen dibandingkan dengan angkatan kerja yang berstatus kawin sebesar 47,34 persen.

\section{Analisis Inferensial}

Estimasi durasi menganggur pada penelitian ini menggunakan regresi Cox. Tabel 5 disajikan hasil output dari model yang paling fit. Berdasarkan tabel 5, partisipasi pelatihan, jenis kelamin, klasifikasi tempat tinggal, dan status perkawinan berpengaruh secara signifikan pada level 5 persen terhadap durasi menganggur. Selain itu, tingkat pendidikan tamat SMA/SMK dan pelatihan program Kartu Prakerja berpengaruh secara signifikan pada level 10 persen terhadap durasi menganggur. Sedangkan tingkat pendidikan tamat perguruan tinggi, tingkat pendidikan tamat SD atau SMP, dan umur tidak berpengaruh secara signifikan hingga level 10 persen.

Tabel 5. Hasil Estimasi Durasi Menganggur.

\begin{tabular}{|c|c|c|c|c|}
\hline Nama Variabel & Koefisien & S.E. & Wald & $\operatorname{Exp}(B)$ \\
\hline \multicolumn{5}{|l|}{ Pendidikan } \\
\hline . $\quad$ Tamat Pendidikan Tinggi & $-0,245$ & 0,154 & 2,520 & 0,783 \\
\hline Tamat SMA/SMK & $-0,237^{*}$ & 0,138 & 2,966 & 0,789 \\
\hline . $\quad$ Tamat SD atau SMP & $-0,057$ & 0,138 & 0,171 & 0,945 \\
\hline \multicolumn{5}{|l|}{. $\quad$ Tidak Sekolah/Tidak Tamat SD (Ref) } \\
\hline Pelatihan Bersertifikat & $0,138^{* *}$ & 0,062 & 4,936 & 1,148 \\
\hline Pelatihan Program Kartu Prakerja & $0,344^{*}$ & 0,200 & 2,962 & 1,410 \\
\hline \multicolumn{5}{|l|}{ Jenis Kelamin } \\
\hline . $\quad$ Laki-laki & $0,199^{* * *}$ & 0,054 & 13,556 & 1,220 \\
\hline . $\quad$ Perempuan $(\operatorname{Ref})$ & & & & \\
\hline \multicolumn{5}{|l|}{ Klasifikasi Tempat Tinggal } \\
\hline . $\quad$ Kota & $-0,332^{* * * *}$ & 0,050 & 44,204 & 0,717 \\
\hline \multicolumn{5}{|l|}{ - $\quad$ Desa $(\operatorname{Ref})$} \\
\hline Umur & 0,004 & 0,003 & 2,171 & 1,004 \\
\hline \multicolumn{5}{|l|}{ Status Perkawinan } \\
\hline Kawin & $0,440^{* * *}$ & 0,058 & 58,129 & 1,552 \\
\hline - $\quad$ Lainnya (Ref) & & & & \\
\hline $\begin{array}{l}\text { Keterangan: } \\
* * * \text { signifikan pada level } 1 \% \\
*^{* *} \text { signifikan pada level } 5 \% \\
\text { * signifikan pada level } 10 \% \\
\text { Sumber: Sakernas Agustus } 2020, \text { BPS (diolah) }\end{array}$ & & & & \\
\hline
\end{tabular}


Tingkat pendidikan tamat SMA/SMK berpengaruh signifikan terhadap durasi menganggur. Nilai hazard ratio sebesar 0,789 yang berarti bahwa angkatan kerja yang pernah mengalami PHK akibat dampak pandemi Covid-19 dengan pendidikan tamat SMA/SMK memiliki risiko keluar dari pengangguran lebih lambat 0,789 kali dibandingkan tidak sekolah/tidak tamat SD. Hal ini dikarenakan individu dengan tingkat pendidikan SMA/SMK cenderung lebih selektif dalam menerima pekerjaan dibandingkan dengan individu yang tidak sekolah/tidak tamat SD, sehingga lebih panjang durasi menganggurnya. Hasil studi ini sesuai dengan hasil studi Pasay \& Indrayanti (2012) bahwa tingkat pendidikan yang semakin tinggi maka cenderung semakin lama durasi menganggurnya.

Selain itu, partisipasi pelatihan bersertifikat dan pelatihan program Kartu Prakerja juga berpengaruh signifikan terhadap durasi menganggur pada angkatan kerja yang pernah mengalami PHK akibat pandemi Covid-19. Risiko keluar dari pengangguran pada individu yang berpartisipasi pelatihan bersertifikat lebih cepat 1,148 kali dibandingkan tidak berpartisipasi pelatihan yang bersertifikat. Begitu pula pada partisipasi pelatihan program Kartu Prakerja, bahwa risiko keluar dari pengangguran pada individu yang mengikuti pelatihan program Kartu Prakerja lebih cepat 1,410 kali dibandingkan tidak mengikuti pelatihan program Kartu Prakerja. Berdasarkan hasil penelitian, pelatihan dapat mengurangi durasi menganggur yang berimplikasi pada penurunan angka pengangguran. Hal ini sesuai dengan penyataan Becker (1962) bahwa pendidikan dan pelatihan merupakan investasi yang penting dalam modal manusia (human capital) dan memiliki pengaruh terhadap pekerjaan.

Jenis kelamin juga berpengaruh signifikan terhadap durasi menganggur pada angkatan kerja yang pernah mengalami PHK akibat pandemi Covid-19. Nilai hazard ratio sebesar 1,220 yang berarti bahwa individu yang berjenis kelamin laki-laki memiliki risiko keluar dari pengangguran yang lebih cepat 1,220 kali dibandingkan perempuan. Temuan ini sejalan dengan penelitian Tansel \& Tasci (2004) di Turki. Lakilaki cenderung memiliki tanggung jawab menafkahi keluarga sehingga mendorong lebih cepat untuk mendapatkan pekerjaan.

Selain itu, klasifikasi tempat tinggal juga berpengaruh signifikan terhadap durasi menganggur pada angkatan kerja yang pernah mengalami PHK akibat dampak pandemi Covid-19. Individu yang tinggal di perkotaan memiliki risiko keluar dari pangangguran lebih lambat 0,717 kali dibandingkan di perdesaan. Temuan ini tidak sesuai dengan penelitian Tansel \& Tasci (2004) di Turki bahwa individu yang tinggal di perkotaan memiliki peluang keluar dari pengangguran lebih besar dibandingkan di perdesaan. Hal ini dikarenakan banyak lapangan kerja sektor formal di perkotaan mengalami kebangkrutan akibat pandemi Covid-19, sehingga individu cenderung mendapatkan pekerjaan di perdesaan yang lebih dominan sektor pertanian (sektor informal).

Status perkawinan pada angkatan kerja yang pernah mengalami PHK akibat dampak pandemi Covid-19 berpengaruh signifikan terhadap durasi menganggur. Nilai hazard ratio sebesar 1,552 yang berarti bahwa individu yang berstatus kawin memiliki risiko keluar dari pengangguran lebih cepat 1,552 kali dibandingkan individu yang berstatus selain kawin. Hasil penelitian ini sejalan dengan temuan Tansel \& Tasci (2004) di Turki. Individu yang berstatus kawin mempunyai tanggung jawab ekonomi yang lebih besar terhadap keluarganya, sehingga mendorong individu untuk lebih cepat mendapatkan pekerjaan guna memperoleh penghasilan.

\section{KESIMPULAN}

Penelitian ini menghasilkan beberapa kesimpulan. Pertama, angkatan kerja yang kembali bekerja setelah terkena PHK akibat dampak pandemi Covid-19 memiliki rata-rata durasi menganggur sebesar 1,57 bulan. Kedua, angkatan kerja yang pernah terkena PHK akibat pandemi Covid-19 didominasi oleh individu yang memiliki pendidikan tamat SMA/SMK/Sederajat, tidak berpartisipasi pelatihan (baik pelatihan bersertifikat dan pelatihan program Kartu Prakerja), berumur 31,51 tahun, berjenis kelamin laki-laki, tinggal di perkotaan, dan berstatus kawin. Ketiga, variabel tingkat pendidikan tamat SMA/SMK dan pelatihan bersertifikat berpengaruh secara signifikan terhadap durasi menganggur. Angkatan kerja yang pernah terkena PHK akibat pandemi Covid-19 dengan tingkat pendidikan tamat SMA/SMK memiliki risiko keluar dari pengangguran yang lebih lambat dibandingkan tidak sekolah/tidak tamat SD. Sedangkan, angkatan kerja yang pernah terkena PHK akibat dampak pandemi Covid-19 yang pernah mengikuti pelatihan bersertifikat memiliki risiko keluar dari pengangguran yang lebih cepat dibandingkan tidak pernah mengikuti pelatihan bersertifikat. Selain itu, variabel kontrol berupa pelatihan program Kartu Prakerja, jenis kelamin, status perkawinan, dan klasifikasi tempat tinggal juga memiliki pengaruh yang signifikan terhadap durasi menganggur. 


\section{UCAPAN TERIMA KASIH}

Penulis mengucapkan terima kasih kepada Badan Pusat Statistik selaku instansi kerja yang memberikan kesempatan menjalani tugas belajar, Pusbindiklatren Bappenas selaku pemberi beasiswa gelar, serta Bapak Padang Wicaksono, Ph.D. dan seluruh Pengajar pada Program Studi Magister Ekonomi Kependudukan dan Ketenagakerjaan Universitas Indonesia atas ilmu yang diberikan selama perkuliahan sehingga penulis dapat menyelesaikan penelitian ini.

\section{DAFTAR PUSTAKA}

Becker, G. S. (1962). Investment in Human Capital: A Theoretical Analysis. Journal of Political Economy, 70(5, Part 2), 9-49. https://doi.org/10.1086/258724

Borjas, G. (2015). Labor Economics 7th Edition (7th ed.). McGraw-Hill Education, 2 Penn Plaza, New York, NY 10121.

BPS. (2020). Buku Pedoman Pencacahan Survei Angkatan Kerja Nasional Agustus 2020. In BPS. BPS.

Crépon, B., Ferracci, M., \& Fougère, D. (2012). Training the Unemployed in France: How Does it Affect Unemployment Duration and Recurrence? Annals of Economics and Statistics, 107/108, 175. https://doi.org/10.2307/23646576

Grogan, L., \& Van Den Berg, G. J. (2001). The duration of unemployment in Russia. Journal of Population Economics, 14(3), 549-568. https://doi.org/10.1007/s001480000029

ILO. (2020). Pemantauan ILO Edisi ke-2 : COVID-19 dan Dunia Kerja. Estimasi dan Analisis Terbaru. International Labour Organization, April, 1-12. https://www.ilo.org/wcmsp5/groups/public/---asia/--ro-bangkok/---ilo-jakarta/documents/publication/wcms_741476.pdf

Mccall, A. J. J. (1970). Economics of Information and Job Search. The Quarterly Journal of Economics, 84(1), 113-126. https://doi.org/10.2307/1879403

OECD. (2020). Skill measures to mobilise the workforce during the COVID-19 crisis. Tackling Coronavirus (COVID-19), July, 1-17. http://www.oecd.org/coronavirus/policy-responses/skill-measures-to-mobilisethe-workforce-during-the-covid-19-crisis-afd33a65/

Pasay, N. H. A., \& Indrayanti, R. (2012). Pengangguran, Lama Mencari Kerja, dan Reservation Wage Tenaga Kerja Terdidik. Jurnal Ekonomi Dan Pembangunan Indonesia, 12(2), 116-135. https://doi.org/10.21002/jepi.v12i2.493

Tansel, A., \& Tasci, H. M. (2004). Determinants of Unemployment Duration for Men and Women in Turkey. IZA Discussion Paper, 1258. http://ftp.iza.org/dp1258.pdf 